\title{
Regulamin Testowego programu edukacyinego Neurologii i Neurochirurgii Polskiej
}

1. Testowy program edukacyjny publikowany na łamach dwumiesięcznika Neurologia i Neurochirurgia Polska, określany dalej jako program, jest przeznaczony dla lekarzy.

2. Program ma akredytację Polskiego Towarzystwa Neurologicznego i Polskiego Towarzystwa Neurochirurgów.

3. Na podstawie rozporządzenia Ministra Zdrowia z 6 października 2004 r. w sprawie sposobów dopełniania obowiązków doskonalenia zawodowego lekarzy i lekarzy dentystów (DzU z 2004 r., Nr 231, pozycja 2326) za udział w programie organizator przyznaje punkty edukacyjne.

4. Program ma formę pytań testowych dotyczących problemów poruszanych w bieżącym numerze czasopisma, na które tylko jedna z zaproponowanych odpowiedzi jest prawidłowa.

5. Organizator przyznaje 0,2 pkt za jedno prawidłowo rozwiązane pytanie testowe.

6. Na początku roku kalendarzowego każdy z uczestników programu otrzymuje zaświadczenie o liczbie punktów uzyskanych w roku ubiegłym.

7. Program jest publikowany w każdym numerze Neurologii $i$ Neurochirurgii Polskiej oraz na stronie internetowej czasopisma www.neurologia.termedia.pl/edu.

8. Odpowiedzi na pytania można udzielać za pośrednictwem strony internetowej po wcześniejszym zalogowaniu się.

9. Na każdy zestaw pytań uczestnik programu może odpowiadać tylko raz, a organizator uważa za ważny pierwszy otrzymany zestaw odpowiedzi.

10. Odpowiedzi można udzielać w nieprzekraczalnym terminie podanym każdorazowo wraz z zestawem pytań.

11. W związku z art. 23 ust. 1 pkt. 1 i ust. 2 ustawy z 29.08.1997 r. o ochronie danych osobowych (DzU nr 133, poz. 883), biorąc udział w programie, uczestnik wyraża zgodę na przetwarzanie przez redakcję Neurologii i Neurochirurgii Polskiej, w celach związanych z działalnością wydawniczą, w systemach informatycznych i w innych zbiorach danych, swoich danych osobowych.

\section{Program edukacyjny - pytania testowe do numeru 3/2010 Neurologii i Neurochirurgii Polskiej}

Odpowiedzi na poniższe pyłania należy udzielić w nieprzekraczalnym terminie do 30 sierpnia $2010 \mathrm{r}$.

1. Najczęstsze ataksje móżdżkowo-rdzeniowe w polskiej populacji to w kolejności:
a) SCA1, SCA2, SCA3
b) SCA1, SCA2, SCA8,
c) SCA1, SCA2, SCA17,
d) SCA2, SCA1, SCA3,
e) SCA2, SCA3, DRPLA.

2. Brak wytrwałości w leczeniu wśród chorych na chorobę Wilsona wiq̨że się z:
a) rodzajem zażywanego leku,
b) wiekiem,
c) płcia,
d) wykształceniem,
e) rodzajem objawów klinicznych - jest częstszy u osób z objawami uszkodzenia wątroby.

3. Wśród chorych na zespół Gillesa de la Tourette'a stężenie kwasu glutaminowego lub GABA w surowicy korelowało z:
a) wiekiem w chwili badania,
b) wiekiem w chwili zachorowania,
c) obecnością zaburzeń zachowania lub dodatkowych zaburzeń psychicznych,
d) płcia,
e) czasem trwania choroby. 
4. Wraz z upływem czasu chorzy, kłórzy przebyli udar niedokrwienny, coraz częściej wymagają ponownej hospitalizacji na oddziale:
a) neurologicznym,
b) chorób wewnętrznych,
c) opieki paliatywnej,
d) kardiologii,
e) innym.

5. Polimorfizm -A162G genu PON1 u chorych na stwardnienie boczne zanikowe może mieć znaczenie w odniesieniu do:
a) wieku, w którym występuja pierwsze objawy choroby,
b) czasu przeżycia,
c) czasu od rozpoznania do wystapienia zaburzeń oddechowych,
d) występowania opuszkowej postaci choroby,
e) wspótistnienia otępienia czołowo-skroniowego.

6. Do wspólnych cech dystrofii miotonicznej typu 1 i typu 2 nie należy:
a) występowanie zaćmy,
b) niedowład rozpoczynający się od mięśni odsiebnych,
c) dziedziczenie autosomalne dominujące,
d) zwiększona aktywność CPK,
e) występowanie zaburzeń przewodzenia w sercu.

7. Wpływ głębokiej stymulacji mózgu na czynności autonomiczne u chorych na chorobę Parkinsona jest kontrowersyjny. Wyniki badań względnie jednoznacznie wskazują na poprawę w zakresie:
a) nagłej potrzeby oddania moczu,
b) zaburzeń czynności seksualnych u kobiet,
c) motoryki przewodu pokarmowego,
d) zespołu deregulacii dopaminowej,
e) niedociśnienia ortostatycznego.

8. Do typowych nieprawidłowości metabolicznych stwierdzanych w rodzinnej częściowej lipodystrofii należq:
a) niedoczynność tarczycy,
b) hiperkortyzolemia,
c) hiperprolaktynemia,
d) dyslipidemia i upośledzona tolerancja glukozy,
e) nadczynność przyłarczyc.

9. Typowa cechq zespołu Parry'ego-Romberga nie jest:
a) połowiczy zanik twarzy,
b) padaczka,
c) dystonia połowicza,
d) migrena,
e) nerwoból tróidzielny.

10. Do czynników predykcyjnych wystąpienia oporności na leczenie w przypadku padaczki nie należy:
a) duża częstość napadów padaczkowych przed podjęciem leczenia,
b) nieskuteczność pierwszego zastosowanego leku przeciwpadaczkowego,
c) skroniowa lokalizacja ogniska padaczkorodnego i wspótistnienie stwardnienia hipokampa,
d) młodszy wiek w chwili zachorowania,
e) wczesne wystąpienie różnych rodzajów napadów padaczkowych. 